OPEN ACCESS

Edited by:

Feng Wang,

Emory University, United States

Reviewed by:

Xiongjian Rao,

University of Kentucky, United States

Xiaoting Zhang,

The Chinese University of Hong Kong,

China

${ }^{*}$ Correspondence:

Weitao Yao

ywt00001@163.com

Specialty section:

This article was submitted to

Cancer Molecular Targets

and Therapeutics,

a section of the journal

Frontiers in Oncology

Received: 28 July 2021

Accepted: 21 September 2021

Published: 05 October 2021

Citation:

Tian Z, Niu X and Yao W (2021) Efficacy and Response Biomarkers of

Apatinib in the Treatment of

Malignancies in China: A Review.

Front. Oncol. 11:749083.

doi: 10.3389/fonc. 2021.749083

\section{Efficacy and Response Biomarkers of Apatinib in the Treatment of Malignancies in China: A Review}

\author{
Zhichao Tian ${ }^{1}$, Xiaohui $\mathrm{Niu}^{2}$ and Weitao Yao ${ }^{1 *}$ \\ 1 Department of Orthopedics, The Affiliated Cancer Hospital of Zhengzhou University and Henan Cancer Hospital, \\ Zhengzhou, China, ${ }^{2}$ Department of Orthopedic Oncology, Beijing Jishuitan Hospital, Beijing, China
}

Apatinib is a multitarget tyrosine kinase inhibitor marketed in China for the treatment of advanced gastric cancer (GC) and hepatocellular carcinoma (HCC). It has also been used off-label for the treatment of many other malignancies. To comprehensively evaluate the efficacy of apatinib as a targeted therapy in the treatment of malignancies, we conducted systematic online and manual searches of the literature on apatinib in the treatment of malignancies. In this review, we first summarized the efficacy of apatinib against various malignancies based on clinical trials where results have been reported. In prospectively registered trials, apatinib has been proven to be effective against GC, HCC, lung cancer, breast cancer, sarcoma, esophageal cancer, colorectal cancer, ovarian cancer, cervical cancer, cholangiocarcinoma, diffuse large B-cell lymphoma, nasopharyngeal carcinoma, and differentiated thyroid cancer. The response biomarkers for apatinib were also reviewed. This review will serve as a good reference for the application of apatinib in clinical studies and the design of clinical trials.

Keywords: apatinib, tyrosine kinase inhibitor, efficacy, response biomarker, clinical trial

\section{INTRODUCTION}

Apatinib is a multitarget tyrosine kinase inhibitor (TKI) developed by Hengrui Pharmaceutical Company, China. The targets that apatinib can inhibit include VEGFR1 $\left(\mathrm{IC}_{50}=70 \mathrm{nM}\right)$, VEGFR2 $(1 \mathrm{nM}), c-R E T(13 \mathrm{nM}), c-K I T(429 \mathrm{nM})$, and c-SRC $(530 \mathrm{nM})$. Current evidence suggests that apatinib has a limited ability to inhibit PDGFR $\alpha\left(\mathrm{IC}_{50}>1000 \mathrm{nM}\right)$, EGFR ( $\left.>10000 \mathrm{nM}\right)$, HER-2 $(>10000 \mathrm{nM})$, and FGFR1 (> $10000 \mathrm{nM})(1)$.

Apatinib was approved for use in China in 2014 for the treatment of advanced gastric adenocarcinoma or gastroesophageal junction adenocarcinoma that had progressed or relapsed after at least two previous systemic chemotherapy treatments (2). Since then, apatinib has been widely used in China not only for advanced gastric cancer (GC) but also for a wide range of other malignancies in an off-label manner (3). In December 2020, apatinib was approved for increased use in China for the treatment of patients with advanced hepatocellular carcinoma (HCC) who had previously failed or were intolerant to at least one first-line systemic therapy. To date, apatinib has shown promising activity against many malignancies $(3,4)$. However, no review articles extensively evaluating the efficacy of apatinib as a targeted therapeutic agent for the treatment of malignancies have been published in the past 3 years. Thus, in this review, we first performed systematic online 
and manual searches of the literature. Next, we summarized the results of all registered clinical trials of apatinib for malignancy treatment and then searched for studies on efficacy markers of apatinib. Finally, based on the review, we have discussed the current problems to be solved in the clinical application of apatinib and the future directions of clinical research.

\section{EFFICACY OF APATINIB IN DIFFERENT MALIGNANCIES}

To fully evaluate the efficacy of apatinib as a targeted therapeutic agent in the treatment of malignancies, systematic online searching and hand searching were conducted. The period included for this search was from January 2005 to July 2021. The inclusion criteria were as follows: 1) trials with a registration number; 2) prospective phase I, II, or III clinical trials; 3) trials of apatinib in the treatment of malignancies; and 4) trials with complete data published in open-access magazines. The retrieved literature and clinical trials were classified according to histological type of disease.

\section{GC}

GC was the first cancer to be tested when apatinib entered clinical trials (Table 1). Results from one of the earliest phase II trials of apatinib for metastatic GC showed that among 144 patients with metastatic GC who had experienced treatment failure with two or more chemotherapy regimens, those treated with apatinib showed improved progression-free survival (PFS) and overall survival (OS) (5). A subsequent phase III clinical trial showed that for the 267 enrolled patients with advanced gastric or gastroesophageal junction adenocarcinoma, for whom two or more prior lines of chemotherapy had failed, apatinib significantly prolonged median OS (6.5 months for the apatinib

TABLE 1 | Clinical trials on apatinib treatment for GC included in this review.

\begin{tabular}{|c|c|c|c|c|c|}
\hline $\begin{array}{l}\text { Type of } \\
\text { disease }\end{array}$ & $\begin{array}{c}\text { Year of } \\
\text { publication }\end{array}$ & Drugs or therapies & $\begin{array}{c}\text { Total } \\
\text { number } \\
\text { of } \\
\text { patients }\end{array}$ & Clinical outcome & References \\
\hline
\end{tabular}

\begin{tabular}{ll}
\hline $\begin{array}{l}\text { Chemotherapy- } \\
\text { refractory }\end{array} 2013$ & $\begin{array}{l}\text { Placebo vs apatinib } 850 \text { mg/day vs apatinib } 425 \\
\text { mg twice daily }\end{array}$
\end{tabular}

advanced metastatic GC

Chemotherapy- $2016 \quad$ Apatinib 850 mg/day or placebo once daily

refractory

advanced or

metastatic

ASGJ

Advanced GC

2020

Apatinib monotherapy or apatinib plus chemotherapy

\begin{tabular}{|c|c|c|}
\hline $\begin{array}{l}\text { Advanced or } \\
\text { metastatic } \\
\text { ASGJ }\end{array}$ & 2020 & Apatinib 500 mg/day \\
\hline $\begin{array}{l}\text { Previously } \\
\text { treated } \\
\text { metastatic GC }\end{array}$ & 2020 & $\begin{array}{l}\text { Apatinib } 250 \text { mg vs apatinib } 425-500 \text { mg vs } \\
\text { apatinib } 675-850 \mathrm{mg} \text { once daily }\end{array}$ \\
\hline $\begin{array}{l}\text { Taxane- } \\
\text { resistant } \\
\text { advanced GC }\end{array}$ & 2020 & $\begin{array}{l}\text { Apatinib } 850 \mathrm{mg} / \text { day in combination with weekly } \\
\text { paclitaxel or the POF regimen }\end{array}$ \\
\hline $\begin{array}{l}\text { Locally } \\
\text { advanced GA }\end{array}$ & 2020 & $\begin{array}{l}\text { Three preoperative cycles of } \mathrm{S}-1 \text { ( } 80-120 \mathrm{mg} / \text { day } \\
\text { on days } 1-14) \text { and oxaliplatin }\left(130 \mathrm{mg} / \mathrm{m}^{2} \text { on day }\right. \\
\text { 1) and two cycles of apatinib ( } 500 \mathrm{mg} / \text { day for } 21 \\
\text { days) at } 3 \text {-week intervals, followed by surgery }\end{array}$ \\
\hline $\begin{array}{l}\text { Advanced } \\
\text { metastatic GC }\end{array}$ & 2020 & $\begin{array}{l}\text { Apatinib } 500 \mathrm{mg} / \text { day, days } 1-21 ; \mathrm{S}-140 \mathrm{mg} / \mathrm{m}^{2} \\
\text { twice daily, days } 1-14\end{array}$ \\
\hline Advanced & 2021 & Apatinib monotherapy or apatinib plus other drugs \\
\hline
\end{tabular}

metastatic

alpha-

fetoprotein-

producing GC

Advanced

ASGJ
144 The median PFS times were 1.40, 3.67, and 3.20 months, respectively. The median OS times were 2.50 , 4.83, and 4.27 months, respectively

267 Median PFS (2.6 vs 1.8 months) and median OS (6.5 vs 4.7 months) were significantly improved in the apatinib group compared with those in the placebo group

737 Patients who received combination therapy achieved significantly longer median PFS (6.18 vs 3.52 months) and median OS (8.72 vs 5.92 months) compared with those who received monotherapy

321 The ORR was $10.60 \%$. The median PFS and OS were 4.0 and 8.2 months, respectively

120 The median PFS and OS were 4.03 and 6.27 months, 4.33 and 7.43 months, and 2.87 and 7.87 months for the low-, mid-, and high-dose groups, respectively, and were comparable between the three dose groups

20 The ORR was $11.1 \%$, the median PFS was 3.5 months, and the median OS was 4.7 months

29 The ORR was $79.3 \%$

30 The median PFS was 4.21 months, and the median OS was 7.49 months

20 The ORR of apatinib was 10\%, the median PFS was 3.5 months, and the median OS was 4.5 months

48 The ORR was 58.3\%, the median PFS was 6.8 months, (14) and the median OS was 14.9 months

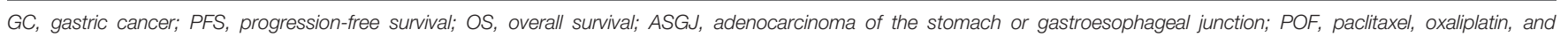
5-fluorouracil; ORR, objective response rate; GA, gastric adenocarcinoma. 
group $v s 4.7$ months for the placebo group) and median PFS (2.6 months for the apatinib group vs 1.8 months for the placebo group) compared with placebo (6). As a result, apatinib was approved for marketing in China in 2014 (2, 15). However, the two clinical trials have attracted criticism and skepticism. These criticisms include: 1) compared with the placebo group, the apatinib group showed limited improvement in survival of GC patients; 2) the analysis of the basic measures was insufficient, and in some of the parameters, there were large differences between the trial and placebo groups; 3) the toxicity analysis was insufficient, considering apatinib was highly toxic at a dose of $850 \mathrm{mg} /$ day (1619). However, these doubts have not affected the large-scale clinical use of apatinib in patients with advanced GC in China.

Subsequent clinical trial results revealed that apatinib showed acceptable efficacy and safety in real-world Chinese patients with metastatic GC $(7,8)$; low doses of apatinib $(250 \mathrm{mg}$ or $500 \mathrm{mg} /$ day $)$ were tolerated by and beneficial to patients with advanced GC who had been heavily treated previously (9), and a lower dose of apatinib achieved comparable OS and PFS with a higher daily dose of apatinib while maintaining better safety (20). Apatinib has been further tested in other therapeutic scenarios. The findings suggested that apatinib combined with paclitaxel-based chemotherapy might be effective and tolerable in patients with chemotherapy-refractory GC (10); apatinib combined with S-1 was not superior to other chemotherapy regimens as first-line therapy for advanced GC (12); apatinib plus neoadjuvant chemotherapy followed by resection in patients with locally advanced gastric adenocarcinoma showed favorable activity and manageable safety (11); apatinib showed promising efficacy and an acceptable safety profile in patients with advanced alpha-fetoprotein-producing GC (13). According to the results of a recent clinical trial, apatinib combined with chemotherapy and PD-1 inhibitor exerted encouraging antitumor activity and manageable toxicity as first-line therapy for patients with advanced or metastatic gastric or gastroesophageal junction adenocarcinoma (14). In general, apatinib is currently considered a third-line or higher-line treatment option for advanced GC in China and is being continuously tested in combination therapies and various treatment scenarios for GC.

\section{HCC}

The clinical trials of apatinib for HCC have only been conducted in recent years (Table 2). Results from a clinical trial in 2017 showed that transcatheter arterial chemoembolization (TACE) in combination with apatinib was superior to TACE alone in the long-term treatment of advanced HCC. The combination of TACE with apatinib can prolong the PFS of patients and has confirmed safety (21). In 2020, a phase III clinical trial of apatinib for advanced HCC showed that apatinib significantly improved OS in patients with pretreated advanced HCC compared to placebo (median 8.7 vs. 6.8 months, respectively), with a manageable safety profile (26). This result led to the approval of apatinib by the China Food and Drug Administration in late 2020 as an agent for additional indications in advanced HCC. Other clinical trials also confirmed the efficacy and safety of apatinib in advanced $\operatorname{HCC}(22,23)$. Apatinib combined with a PD-1 inhibitor showed promising efficacy and manageable safety in patients with advanced HCC both in the first- and second-line settings, and apatinib at a dose of $250 \mathrm{mg}$ was recommended as a combination therapy for advanced HCC treatment in further studies $(24,25)$. Based on the above clinical trial results, apatinib combined with PD-1 inhibitors has the potential to replace apatinib monotherapy in the treatment of advanced HCC (27). With its approval for the treatment of advanced HCC, apatinib will be further studied in the treatment of HCC. At present, the importance of apatinib in the treatment of HCC is significantly superior to its importance in GC treatment.

TABLE 2 | Clinical trials on apatinib for HCC treatment included in this review.

\begin{tabular}{|c|c|c|c|c|c|}
\hline Type of disease & $\begin{array}{l}\text { Year of } \\
\text { publication }\end{array}$ & Drugs or therapies & $\begin{array}{c}\text { Number } \\
\text { of } \\
\text { patients }\end{array}$ & Clinical outcome & References \\
\hline Intermediate and advanced HCC & 2017 & $\begin{array}{l}\text { TACE alone vs TACE } \\
\text { with apatinib }\end{array}$ & 44 & $\begin{array}{l}\text { The median PFS was } 6.0 \text { months in the TACE group and } 12.5 \\
\text { months in the TACE with apatinib group, with significant difference }\end{array}$ & $(21)$ \\
\hline Advanced HCC & 2020 & Apatinib 500 mg/day & 22 & $\begin{array}{l}\text { The ORR was } 30.4 \% \text {. The median OS and PFS were } 13.8 \text { and } 8.7 \\
\text { months, respectively }\end{array}$ & $(22)$ \\
\hline $\begin{array}{l}\text { Patients after resection of } \mathrm{HCC} \\
\text { with PVTT }\end{array}$ & 2020 & Apatinib 500 mg/day & 30 & $\begin{array}{l}\text { The median RFS was } 7.6 \text { months. The 1-year PFS rate and 1-year } \\
\text { OS rate were } 36.1 \% \text { and } 93.3 \% \text {, respectively }\end{array}$ & (23) \\
\hline Advanced HCC & 2020 & $\begin{array}{l}\text { Camrelizumab } 200 \\
\text { mg every } 2 \text { weeks } \\
\text { plus apatinib } 250 \mathrm{mg} / \\
\text { day }\end{array}$ & 190 & $\begin{array}{l}\text { The ORR was } 34.3 \% \text { and } 22.5 \% \text { in the first- and second-line } \\
\text { cohorts, respectively. The median PFS in the cohorts was } 5.7 \text { and } \\
5.5 \text { months, respectively. The } 12 \text {-month survival rate was } 74.7 \% \text { and } \\
68.2 \% \text {, respectively }\end{array}$ & $(24)$ \\
\hline $\begin{array}{l}\text { Advanced primary liver cancer } \\
\text { after prior systemic treatment(s) }\end{array}$ & 2021 & $\begin{array}{l}\text { Camrelizumab } 200 \\
\text { mg every } 2 \text { weeks } \\
\text { plus apatinib 125- } \\
500 \text { mg/day }\end{array}$ & 28 & $\begin{array}{l}\text { The ORR was } 10.7 \% \text {. The median PFS and OS were } 3.7 \text { and } 13.2 \\
\text { months, respectively }\end{array}$ & (25) \\
\hline $\begin{array}{l}\text { Advanced HCC refractory or } \\
\text { intolerant to at least one line of } \\
\text { systemic chemotherapy or } \\
\text { targeted therapy }\end{array}$ & 2021 & $\begin{array}{l}\text { Apatinib } 750 \text { mg or } \\
\text { placebo orally once } \\
\text { daily }\end{array}$ & 393 & $\begin{array}{l}\text { The median OS was significantly improved in the apatinib group } \\
\text { compared with that in the placebo group (median } 8.7 \text { vs } 6.8 \text { months) }\end{array}$ & $(26)$ \\
\hline
\end{tabular}

HCC, hepatocellular carcinoma; TACE, transcatheter arterial chemoembolization; PFS, progression-free survival; ORR, objective response rate; OS, overall survival; PVTT, portal vein tumor thrombosis; SBRT, stereotactic body radiotherapy. 


\section{Lung Cancer}

In addition to the two approved indications above, lung cancer is the indication with the largest number of apatinib-related clinical trials (Table 3). In 2018, a phase II clinical trial showed that apatinib had some efficacy with an objective response rate (ORR) of $13.2 \%$ and a median PFS of 3.06 months, and manageable toxicity in patients with advanced non-squamous non-small-cell lung cancer (NSCLC) (28). Although this trial revealed only a

TABLE 3 | Clinical trials on apatinib for lung cancer treatment included in this review.

\begin{tabular}{|c|c|c|c|c|c|}
\hline Type of disease & $\begin{array}{c}\text { Year of } \\
\text { publication }\end{array}$ & Drugs or therapies & $\begin{array}{c}\text { Number } \\
\text { of } \\
\text { patients }\end{array}$ & Clinical outcome & References \\
\hline
\end{tabular}

\begin{tabular}{lll}
\hline $\begin{array}{l}\text { Pretreated advanced non- } \\
\text { squamous NSCLC }\end{array}$ & 2018 & Apatinib 750 or 500 mg/day \\
$\begin{array}{lll}\text { Advanced lung } \\
\text { adenocarcinoma }\end{array}$ & 2019 & $\begin{array}{l}\text { Apatinib } 250-500 \text { mg/day and docetaxel } \\
\text { Extensive-stage SCLC }\end{array}$ \\
& $2019 \quad \begin{array}{l}\text { Apatinib } 250 \text { mg/day during the chemotherapy } \\
\text { interval, and as maintenance therapy after 4-6 } \\
\text { cycles }\end{array}$
\end{tabular}

40 The ORR was $13.2 \%$, the median PFS was 3.06 months, and the median OS was 7.69 months

12 The median PFS was 2.76 months

Extensive-stage SCLC after two or three previous treatments, including a platinum-based regimen Extensive-stage SCLC

Advanced lung squamous cell carcinoma

Extensive-stage SCLC after

failure of two or more lines of chemotherapy Advanced non-squamous NSCLC with wild-type EGFR

Chemo-naive nonsquamous NSCLC

Unresectable locally advanced or advanced NSCLC without driver mutations that had progressed following firstline chemotherapy Wild-type advanced NSCLC after second-line treatment failure Advanced non-squamous NSCLC harboring EGFR 19 deletion or $21 \mathrm{~L} 858 \mathrm{R}$ point mutation

Advanced non-squamous NSCLC previously treated with chemotherapy

Extensive-stage SCLC that had progressed following two to three previous therapies

Advanced EGFR-mutant NSCLC

\section{Apatinib 500 mg/day}

Apatinib 375 mg/day plus camrelizumab 200 mg every 2 weeks

2020 Apatinib 250 mg/day

2020 Apatinib 500 mg/day

2020 Apatinib 500 mg/day plus intravenous docetaxel $\left(60 \mathrm{mg} / \mathrm{m}^{2}\right.$ at day 1 every 3 weeks for $4-6$ cycles)

2020 Apatinib $250 \mathrm{mg} /$ day with intravenous pemetrexed $\left(500 \mathrm{mg} / \mathrm{m}^{2}\right.$ )-platinum (carboplatin $\mathrm{AUC}=5$ or cisplatin $75 \mathrm{mg} / \mathrm{m}^{2}$ ) chemotherapy every 21 days for six treatment cycles, followed by maintenance with apatinib $250 \mathrm{mg}$ once daily 2020 Apatinib combined with four cycles of docetaxel or pemetrexed

2020 Apatinib $500 \mathrm{mg} /$ day and oral vinorelbine $60 \mathrm{mg} / \mathrm{m}^{2}$ once weekly

2020 Cohort A (apatinib 500 mg + gefitinib 250 mg) vs Cohort B (apatinib 250 mg + gefitinib 250 mg)

2020 Apatinib 250-500 mg/day in combination with intravenous camrelizumab 200 mg every 2 weeks

2021 Apatinib (250 mg/day continuously) and etoposide capsules (50 mg/day, on days 1-21, per 28 days)

$2021 \quad$ A+G group (apatinib 500 mg/day plus gefitinib $250 \mathrm{mg} /$ day) vs $\mathrm{P}+\mathrm{G}$ group (placebo plus gefitinib $250 \mathrm{mg} /$ day)
24 The median PFS was 7.8 and 4.9 months in the combination and chemotherapy groups, respectively. The median OS was 12.1 and 8.2 months in the combination and chemotherapy groups, respectively

40 The ORR was $18.4 \%$, the median PFS was 3.0 months, and the median OS was 5.8 months

47 The ORR was $34.0 \%$, the median PFS was 3.6 months, and the median OS was 8.4 months

36 The ORR was $16.7 \%$, the median PFS was 4.9 months, and the median OS was 6.9 months

22 The ORR was $13.6 \%$, the median PFS was 5.4 months, and the median OS was 10.0 months

29 The ORR was $27.6 \%$, the median PFS was 5.3 months, and the median OS was 9.6 months

20 The ORR was $80 \%$, the median PFS was 7.7 months, and the median OS was 20.1 months

33 The ORR was $27 \%$, and the median PFS was 5.47 months

30 The ORR was $36.7 \%$, the median PFS was 4.5 months, and the median OS was 10.0 months

13 Of the 11 patients evaluable for efficacy, Cohort A achieved an ORR of $80.0 \%$ and reached a median PFS of 19.2 months, whereas Cohort B attained an ORR and median PFS of $83.3 \%$ and 13.4 months, respectively

105 In the efficacy-evaluable population $(n=94)$, the ORR was 30.9\%, the median PFS was 895.7 months, and the overall survival was 15.5 months

53 The ORR was $20.8 \%$, the median PFS was 3.0 months, and the median OS was 5.0 months

313 The median PFS was 13.7 vs 10.2 months in the $A+G$ group vs the $P+G$ group, respectively

NSCLC, non-small-cell lung cancer; ORR, objective response rate; PFS, progression-free survival; OS, overall survival. 
modest efficacy of apatinib against NSCLC, this drug has been increasingly tested in lung cancer. Results from the next three phase II clinical trials suggested that apatinib exhibited efficacy and an acceptable safety profile in previously heavily treated extensive-stage small-cell lung cancer (SCLC) patients. Further exploration of apatinib in phase III trials is warranted $(30,31$, 34). Another phase II clinical trial reported that low-dose apatinib monotherapy might be an option for patients with advanced lung squamous cell carcinoma (33). These clinical trial results indicated that apatinib exerted some clinical activity against all lung cancer subtypes but did not have an advantage over several other lung cancer treatment agents. Owing to the limited efficacy of apatinib as a single agent in lung cancer, an increasing number of clinical trials have begun to investigate apatinib plus alternative agents or therapies, the most common of which is apatinib in combination with chemotherapy. These clinical trials included a phase I trial of apatinib plus docetaxel in advanced lung adenocarcinoma (29); a multicenter, phase II trial of apatinib plus docetaxel in advanced non-squamous NSCLC (35); a phase II trial of apatinib in combination with pemetrexed-platinum chemotherapy in chemo-naive non-squamous NSCLC (36); a randomized, controlled, multicenter clinical trial of apatinib plus docetaxel or pemetrexed in unresectable NSCLC (37); a nonrandomized clinical trial of apatinib plus vinorelbine in wild-type advanced NSCLC (38); and an open-label, multicenter, single-arm phase II trial of apatinib with etoposide capsules in extensive-stage SCLC (41). These studies conclude that apatinib combined with chemotherapy shows promising efficacy and manageable toxicity in enrolled patients. Apatinib plus chemotherapy seemed to be more effective than apatinib alone, and there was no significant increase in toxicity. However, as there are no randomized controlled clinical trials, we cannot identify the difference between the combination regimen and the monotherapy regimen. In addition, phase II and III trials have shown that apatinib plus gefitinib as first-line therapy resulted in superior PFS to placebo plus gefitinib in advanced EGFR-mutant NSCLC. Combination therapy resulted in more adverse events but did not interfere with the quality of life of patients $(39,42)$.
Finally, combined apatinib and camrelizumab showed encouraging antitumor activity and acceptable toxicity in both advanced SCLC (32) and non-squamous NSCLC patients (40). These results suggest that apatinib has great potential in combination with other targeted or immunological agents. In conclusion, apatinib monotherapy has shown activity in all subtypes of lung cancer; however, its efficacy is inferior to that of other established therapies. Currently, apatinib can only be used in combination with other therapies as a treatment option for patients with advanced lung cancer who have failed multiline therapy. In the treatment of advanced lung cancer, the combination of apatinib with other drugs or treatment regimens is the current and next stage of research.

\section{Sarcoma}

Pazopanib was approved by the US Food and Drug Administration in 2014 for increased indications of advanced soft tissue sarcoma (STS) (43). This event inspired clinical researchers in China to apply apatinib, the first domestically produced multitarget TKI similar to pazopanib, in the treatment of sarcoma (Table 4). In 2019, the first phase II clinical trial to report results demonstrated the activity (with an ORR of 15.25\%) and safety of apatinib in the treatment of advanced STSs (44). Another phase II clinical trial showed that apatinib was a sensitive drug for advanced osteosarcoma, with an ORR of $43.24 \%$ after the failure of chemotherapy, with a similar duration of response compared to other TKIs (45). Although the results of these two clinical trials have been somewhat controversial, apatinib is of great interest in the treatment of osteosarcoma and STSs because there are fewer drugs available for advanced sarcomas. In 2020, another phase II trial showed that apatinib showed good efficacy in advanced STS patients, with an ORR of $23.68 \%$ (47). This result evidences the efficacy of apatinib in treating STSs. However, there are more than 70 types of STSs, and different subtypes of STSs respond differently to apatinib. Therefore, it is necessary to validate the efficacy of apatinib in different subtypes. Notably, a phase II trial showed that the combination of apatinib and a PD-1 inhibitor did not prolong PFS in comparison to single-agent apatinib in treating

TABLE 4 | Clinical trials on apatinib for sarcoma treatment included in this review.

\begin{tabular}{|c|c|c|c|c|c|}
\hline Type of disease & $\begin{array}{c}\text { Year of } \\
\text { publication }\end{array}$ & Drugs or therapies & $\begin{array}{l}\text { Number } \\
\text { of } \\
\text { patients }\end{array}$ & Clinical outcome & References \\
\hline $\begin{array}{l}\text { Advanced sarcoma after } \\
\text { chemotherapy failure }\end{array}$ & 2019 & Apatinib 500 mg/day & 59 & $\begin{array}{l}\text { The ORR was } 15.25 \% \text {, and the median PFS was } \\
7.93 \text { months }\end{array}$ & $(44)$ \\
\hline $\begin{array}{l}\text { Advanced osteosarcoma after failure } \\
\text { of standard multimodal therapy }\end{array}$ & 2019 & Apatinib 500-750 mg/day & 37 & $\begin{array}{l}\text { The ORR was } 43.24 \% \text {, the median PFS was } 4.50 \\
\text { months, and the median OS was } 9.87 \text { months }\end{array}$ & $(45)$ \\
\hline Advanced chordoma & 2020 & Apatinib 500 mg/day & 30 & $\begin{array}{l}\text { The ORR was } 3.7 \% \text {, and the median PFS was } 18 \\
\text { months }\end{array}$ & $(46)$ \\
\hline $\begin{array}{l}\text { Advanced STS after the failure of } \\
\text { adriamycin-based chemotherapy }\end{array}$ & 2020 & Apatinib 500 mg/day & 42 & $\begin{array}{l}\text { The ORR was } 23.68 \% \text {, the median PFS was } 7.87 \\
\text { months, and the median OS was } 17.55 \text { months }\end{array}$ & $(47)$ \\
\hline $\begin{array}{l}\text { Advanced osteosarcoma } \\
\text { progressing after chemotherapy }\end{array}$ & 2020 & $\begin{array}{l}\text { Apatinib } 500 \text { mg/day plus } \\
\text { camrelizumab } 200 \text { mg every } 2 \\
\text { weeks }\end{array}$ & 43 & $\begin{array}{l}\text { The ORR was } 20.9 \% \text {, and the } 6 \text {-month PFS rate } \\
\text { was } 50.9 \%\end{array}$ & $(48)$ \\
\hline
\end{tabular}

ORR, objective response rate; PFS, progression-free survival; OS, overall survival; STS, soft tissue sarcoma. 
advanced osteosarcoma (48), which suggests that the efficacy of apatinib plus PD-1 inhibitors in osteosarcoma is very limited. Nevertheless, although the results of clinical trials of apatinib plus PD-1 inhibitor in STSs are not yet available, based on current evidence, such a combination regimen is desirable (49, 50). In conclusion, apatinib represents a significant development in the treatment of osteosarcoma and STSs, although it is less effective than first-line and second-line chemotherapy. A better therapeutic scenario for apatinib in the treatment of sarcomas remains to be developed.

\section{Breast Cancer}

Clinical trials of apatinib in breast cancer began early (Table 5). In 2014, multicenter phase II trials showed that apatinib exhibited objective efficacy and manageable toxicity in heavily pretreated metastatic non-triple-negative breast cancer (NTNBC) (with an ORR of 16.7\%) (51) and in TNBC (with an ORR of $10.7 \%$ ) (52). Although these two clinical trials initially showed that the activity of apatinib in breast cancer was similar to that of other multitarget TKIs of the same class, the efficacy of apatinib was considered limited in breast cancer in comparison to a large number of established therapies (51). Therefore, the activity of apatinib monotherapy against breast cancer has not been further tested. Hopes are pinned on the combination of apatinib and other drugs. In 2020, a phase II trial showed that apatinib combined with etoposide capsules is effective and tolerable in heavily pretreated, metastatic HER2-negative breast cancer patients (53). Another phase II trial showed that the ORR of an apatinib plus PD-1 inhibitor regimen was markedly higher than the previously reported ORR of anti-PD-1/PD-L1 antibody or apatinib monotherapy in advanced TNBC (54). Two recent clinical trials have shown that apatinib is active and safe in combination with endocrine therapy or oral vinorelbine for the treatment of HER2-negative breast cancer $(55,56)$. These four clinical trials with small sample sizes preliminarily proved that apatinib combined with other drugs has promising activity in the treatment of breast cancer. These combination regimens should be validated in large, controlled, prospective clinical trials. In conclusion, the efficacy of apatinib monotherapy in breast cancer is assumed to be limited, and the efficacy of apatinib in combination with other drugs or therapies needs to be further tested.

\section{Esophageal Cancer}

In 2020, a phase II trial showed that apatinib was effective as second- or further-line treatment for advanced esophageal cancer, with an ORR of $7.7 \%(2 / 26)(57)$; another clinical trial involving 40 patients reported similar results (58). The results of these two clinical trials suggested that apatinib monotherapy is not ideal for the treatment of advanced esophageal cancer (Table 6). In another phase II clinical trial, apatinib plus PD-1 inhibitor combined with liposomal paclitaxel and nedaplatin as a first-line treatment showed antitumor activity (with an ORR of $80.0 \%$ ) and manageable safety in patients with advanced esophageal cancer (59). However, it is not possible to make definite interpretations regarding the contribution of apatinib in this complex combination of treatments. In conclusion, based on current evidence, apatinib has moderate efficacy against advanced esophageal squamous cell carcinoma, and clinical trials with large sample sizes are needed to identify the optimal setting for the use of apatinib in esophageal cancer.

\section{Colorectal Cancer}

In 2019, a phase II trial showed that apatinib monotherapy exerted promising efficacy in patients with refractory colorectal cancer, with a median PFS of 3.9 months (Table 6) (60).

TABLE 5 | Clinical trials on apatinib for breast cancer treatment included in this review.

\begin{tabular}{|c|c|c|c|c|c|}
\hline Type of disease & $\begin{array}{c}\text { Year of } \\
\text { publication }\end{array}$ & Drugs or therapies & $\begin{array}{l}\text { Number } \\
\text { of } \\
\text { patients }\end{array}$ & Clinical outcome & References \\
\hline $\begin{array}{l}\text { Heavily pretreated advanced non- } \\
\text { TNBC }\end{array}$ & 2014 & Apatinib 500 mg/day & 38 & $\begin{array}{l}\text { The ORR was } 16.7 \% \text {, the median PFS } \\
\text { was } 4.0 \text { months, and the median OS was } \\
10.3 \text { months }\end{array}$ & (51) \\
\hline $\begin{array}{l}\text { Heavily pretreated metastatic } \\
\text { TNBC }\end{array}$ & 2014 & Apatinib 500 mg/day & 56 & $\begin{array}{l}\text { The ORR was } 10.7 \% \text {, the median PFS } \\
\text { was } 3.3 \text { months, and the median OS was } \\
10.6 \text { months }\end{array}$ & (52) \\
\hline $\begin{array}{l}\text { Heavily pretreated metastatic } \\
\text { breast cancer }\end{array}$ & 2020 & $\begin{array}{l}\text { Apatinib } 450-500 \mathrm{mg} / \text { day, and etoposide } \\
\text { capsules } 50 \mathrm{mg} / \mathrm{m}^{2} \text { on days } 1 \text { to } 10 \text { for } 21 \\
\text { days }\end{array}$ & 31 & $\begin{array}{l}\text { The ORR was } 35.5 \% \text {, the median PFS } \\
\text { was } 6.9 \text { months, and the median OS was } \\
20.4 \text { months }\end{array}$ & (53) \\
\hline $\begin{array}{l}\text { Advanced TNBC after failure of } \\
\text { less than three lines of systemic } \\
\text { therapy }\end{array}$ & 2020 & $\begin{array}{l}\text { Apatinib } 250 \text { mg/day plus camrelizumab } \\
200 \text { mg every } 2 \text { weeks }\end{array}$ & 30 & $\begin{array}{l}\text { The ORR was } 43.3 \% \text {, and the median PFS } \\
\text { was } 3.7 \text { months }\end{array}$ & $(54)$ \\
\hline $\begin{array}{l}\text { HER2-negative breast cancer } \\
\text { involving chest wall metastasis }\end{array}$ & 2021 & Apatinib 500 mg/day & 26 & $\begin{array}{l}\text { The ORR was } 42.3 \% \text {, the median PFS } \\
\text { was } 4.9 \text { months, and the median OS was } \\
18 \text { months }\end{array}$ & (55) \\
\hline $\begin{array}{l}\text { Heavily pretreated HER2-negative } \\
\text { metastatic breast cancer }\end{array}$ & 2021 & $\begin{array}{l}\text { Apatinib } 500 \mathrm{mg} / 425 \mathrm{mg} \text { daily plus oral } \\
\text { vinorelbine } 60 \mathrm{mg} / \mathrm{m}^{2} \text { on days } 1,8 \text {, and } 15 \\
\text { of every cycle }\end{array}$ & 40 & $\begin{array}{l}\text { The ORR was } 17.1 \% \text {, the median PFS } \\
\text { was } 5.2 \text { months, and the median OS was } \\
17.4 \text { months }\end{array}$ & $(56)$ \\
\hline
\end{tabular}

TNBC, triple-negative breast cancer; ORR, objective response rate; PFS, progression-free survival; OS, overall survival. 
TABLE 6 | Clinical trials on apatinib for the treatment of malignant tumors included in this review.

\begin{tabular}{|c|c|c|c|c|c|}
\hline Type of disease & $\begin{array}{c}\text { Year of } \\
\text { publication }\end{array}$ & Drugs or therapies & $\begin{array}{c}\text { Number of } \\
\text { patients }\end{array}$ & Clinical outcome & References \\
\hline $\begin{array}{l}\text { Advanced ESCC or } \\
\text { adenocarcinoma of the esophagus } \\
\text { or esophagogastric junction }\end{array}$ & 2020 & Apatinib 500 mg/day & 26 & $\begin{array}{l}\text { The ORR was } 7.7 \% \text {, } \\
\text { the median PFS was } \\
4.63 \text { months, and the } \\
\text { median OS was } 6.57 \\
\text { months }\end{array}$ & $(57)$ \\
\hline $\begin{array}{l}\text { Unresectable locally advanced or } \\
\text { recurrent/metastatic ESCC }\end{array}$ & 2020 & $\begin{array}{l}\text { Camrelizumab } 200 \mathrm{mg} \text {, liposomal paclitaxel } 150 \mathrm{mg} / \mathrm{m}^{2} \text {, and } \\
\text { nedaplatin } 50 \mathrm{mg} / \mathrm{m}^{2} \text { on day } 1 \text {, and apatinib } 250 \mathrm{mg} \text { on days } \\
\text { 1-14. The treatments were repeated every } 14 \text { days for up to } \\
\text { nine cycles, followed by maintenance therapy with } \\
\text { camrelizumab and apatinib }\end{array}$ & 30 & $\begin{array}{l}\text { The ORR was } 80.0 \% \text {, } \\
\text { the median PFS was } \\
6.85 \text { months, and the } \\
\text { median OS was } 19.43 \\
\text { months }\end{array}$ & (59) \\
\hline $\begin{array}{l}\text { Chemotherapy- refractory } \\
\text { advanced or metastatic ESCC }\end{array}$ & 2021 & Apatinib 500 mg/day & 40 & $\begin{array}{l}\text { The ORR was } 7.5 \% \text {, } \\
\text { the median PFS was } \\
3.8 \text { months, and the } \\
\text { median OS was } 5.8 \\
\text { months }\end{array}$ & (58) \\
\hline $\begin{array}{l}\text { Adenocarcinoma of the colon or } \\
\text { rectum after at least two prior } \\
\text { regimens of standard therapies } \\
\text { including fluoropyrimidine, } \\
\text { oxaliplatin, and irinotecan }\end{array}$ & 2019 & Apatinib 500 mg/day & 26 & $\begin{array}{l}\text { The median PFS was } \\
3.9 \text { months, and the } \\
\text { median OS was } 7.9 \\
\text { months }\end{array}$ & $(60)$ \\
\hline $\begin{array}{l}\text { Microsatellite-stable metastatic } \\
\text { colorectal cancer }\end{array}$ & 2020 & $\begin{array}{l}\text { Camrelizumab } 200 \text { mg every } 2 \text { weeks and apatinib 250-375 } \\
\text { mg/day }\end{array}$ & 10 & $\begin{array}{l}\text { The ORR was } 0 \% \text {, the } \\
\text { median PFS was } 1.83 \\
\text { months, and the median } \\
\text { OS was } 7.80 \text { months }\end{array}$ & $(61)$ \\
\hline $\begin{array}{l}\text { Metastatic colorectal cancer after } \\
\text { failure of two or more lines of } \\
\text { standard fluorouracil-based } \\
\text { chemotherapy }\end{array}$ & 2020 & Apatinib 500 mg/day & 48 & $\begin{array}{l}\text { The ORR was } 8.3 \% \text {, } \\
\text { the median PFS was } \\
4.8 \text { months, and the } \\
\text { median OS was } 9.1 \\
\text { months }\end{array}$ & (62) \\
\hline $\begin{array}{l}\text { Platinum-resistant or platinum- } \\
\text { refractory ovarian cancer }\end{array}$ & 2018 & $\begin{array}{l}\text { Apatinib } 500 \text { mg/day on a continuous basis, and oral } \\
\text { etoposide at a dose of } 50 \text { mg once daily on days } 1-14 \text { of a } \\
21 \text {-day cycle. Oral etoposide was administered for a maximum } \\
\text { of six cycles }\end{array}$ & 35 & The ORR was $54 \%$ & (63) \\
\hline $\begin{array}{l}\text { Advanced cervical cancer that had } \\
\text { progressed after at least one line } \\
\text { of systemic therapy }\end{array}$ & 2020 & $\begin{array}{l}\text { Camrelizumab } 200 \text { mg every } 2 \text { weeks and apatinib } 250 \text { mg/ } \\
\text { day }\end{array}$ & 45 & $\begin{array}{l}\text { The ORR was } 55.6 \% \text {, } \\
\text { and the median PFS } \\
\text { was } 8.8 \text { months }\end{array}$ & $(64)$ \\
\hline $\begin{array}{l}\text { Advanced cholangiocarcinoma } \\
\text { after refractory chemotherapy }\end{array}$ & 2021 & Apatinib 500 mg/day & 26 & $\begin{array}{l}\text { The ORR was } 11.5 \% \text {, } \\
\text { the median PFS was } \\
2.0 \text { months, and the } \\
\text { median OS was } 9.0 \\
\text { months }\end{array}$ & (65) \\
\hline $\begin{array}{l}\text { Relapsed or refractory diffuse large } \\
\text { B-cell lymphoma }\end{array}$ & 2020 & Apatinib 500 mg/day & 32 & $\begin{array}{l}\text { The ORR was } 43.8 \% \text {, } \\
\text { the median PFS was } \\
6.9 \text { months, and the } \\
\text { median OS was } 7.9 \\
\text { months }\end{array}$ & (66) \\
\hline $\begin{array}{l}\text { Metastatic or locoregionally } \\
\text { recurrent nasopharyngeal } \\
\text { carcinoma after refractory of } \\
\text { chemotherapy }\end{array}$ & 2021 & Apatinib 500 mg/day & 33 & $\begin{array}{l}\text { The ORR was } 36.4 \% \text {, } \\
\text { the median PFS was } 5 \\
\text { months, and the } \\
\text { median OS was } 16 \\
\text { months }\end{array}$ & $(67)$ \\
\hline $\begin{array}{l}\text { Progressive radioiodine-refractory } \\
\text { differentiated thyroid cancer }\end{array}$ & 2021 & Apatinib 500 mg/day & 20 & $\begin{array}{l}\text { The ORR was } 80 \% \text {, } \\
\text { the median PFS was } \\
18.4 \text { months, and the } \\
\text { median OS was } 51.6 \\
\text { months }\end{array}$ & $(68)$ \\
\hline
\end{tabular}

ESCC, esophageal squamous cell carcinoma; ORR, objective response rate; PFS, progression-free survival; OS, overall survival.

In another trial, apatinib monotherapy exhibited encouraging efficacy (with an ORR of $8.3 \%$ and a median PFS of 4.8 months) with manageable toxicities in chemotherapy-refractory metastatic colorectal cancer (62). These results indicate that apatinib has a certain efficacy against colorectal cancer, which is worthy of further verification in clinical trials with larger sample sizes. However, results from another phase II clinical trial, already published in 2020 , showed that combination with a 
PD-1 inhibitor failed to improve the efficacy of apatinib in treating metastatic colorectal cancer (61). The researchers concluded that this situation was caused by insufficient effective doses due to the high toxicity of the combination therapy. In conclusion, apatinib may have moderate activity against colorectal cancer. Clinical trials with large sample sizes are needed to determine whether apatinib is more efficacious as a single agent or in combination with other agents for the treatment of advanced colorectal cancer.

\section{Other Cancers}

In 2018, a phase II trial showed that the combination of apatinib with oral etoposide showed promising efficacy (with an ORR of 54.3\%) and manageable toxicities in patients with platinum-resistant or platinum-refractory ovarian cancer (Table 6) (63). However, the study had a small sample size, and the significance of apatinib in this combination regimen is unclear (69). The activity of apatinib in ovarian cancer needs to be further validated in clinical trials with large sample sizes. As in ovarian cancer, only one phase II clinical trial has reported the activity of apatinib in advanced cervical cancer. This clinical trial showed that apatinib plus PD-1 inhibitor showed promising antitumor activity (with an ORR of 55.6\%) and manageable toxicities in patients with advanced cervical cancer (64). Larger randomized controlled trials are warranted to validate these findings.

In addition, several recent phase II clinical trials have confirmed that apatinib monotherapy has certain efficacy and good safety in the treatment of advanced cholangiocarcinoma (ORR, 11.5\%) (65), relapsed or refractory diffuse large B-cell lymphoma (ORR, 43.8\%) (66), metastatic or locoregionally recurrent nasopharyngeal carcinoma (ORR, 36.4\%) (67), and radioiodine-refractory differentiated thyroid cancer (ORR, $80 \%$ ) (68). These clinical trials have only initially shown the efficacy and safety of apatinib in these malignancies (Table 6). Therefore, we cannot conclude the true efficacy of apatinib in these malignancies owing to the small sample sizes of these single-arm clinical trials. Extensive clinical trials are needed to confirm the efficacy and optimal use of apatinib in these malignancies.

\section{BIOMARKERS OF RESPONSE TO APATINIB IN DIFFERENT MALIGNANCIES}

In addition to efficacy and safety in various malignancies, response biomarkers are an important topic in clinical research of apatinib. We searched all literature related to potential biomarkers of the antitumor efficacy of apatinib in the treatment of malignancies and screened out all possible efficacy biomarkers currently reported. The results are presented in Tables 7 and 8 .

As shown in Tables $\mathbf{7}$ and $\mathbf{8}$, several potential biomarkers have been reported to predict the response of patients to apatinib. According to the predicted outcomes, these biomarkers can be classified as those associated with improved outcomes (Table 7) or those associated with poor outcomes (Table 8). Based on their properties, these biomarkers can be divided into three categories: adverse event markers, routine test markers, and genetic test markers. Adverse event markers include hypertension, proteinuria, hand and foot syndrome (HFS), lung cavitation, anorexia, pneumothorax, and hypothyroidism. Routine test markers include phosphorylated VEGFR2, higher baseline TILs or a greater increase in tumorinfiltrating CD8+ T cells during therapy, lower baseline plasma HGF/IL-8, a decrease in plasma IL-8, an increase in plasma TIM3/CD152 during therapy, higher baseline CD4+ T-cell or B-cell proportion in blood, leukopenia, platelet-to-lymphocyte ratio, lymphocyte-to-monocyte ratio, prognostic nutritional index, clinical-radiomics nomograms, adipose tissue area, neutrophilto-lymphocyte ratio, and carbohydrate antigen 19-9. Genetic test markers include cfDNA concentration, MIKI67 mutations, HPD-related mutations, STK11/KEAP1, PIK3CA, PTEN, ERBB3, PI3K/AKT, and TMB mutations.

Nevertheless, owing to high technical requirements and cost, it is difficult to screen for genetic test biomarkers on a large scale in clinical practice. In contrast, adverse event and routine test biomarkers are highly effective and can be easily implemented in various diagnostic and treatment institutions on a large scale. However, although many potential prognostic markers of apatinib have been reported, none of them have been widely used in clinical practice. The main reasons include the following: First, the level of the currently available evidence is not high; current studies on the potential biomarkers of apatinib are either retrospective studies or adjunct to efficacy and safety trials, and only a few prospectively registered trials have focused on prognostic biomarkers. Second, prognostic biomarker studies are still in the exploratory stage. Significant differences in efficiency were observed between different types of markers in various malignancies. Third, the prediction efficiency of individual markers is not high, leading to a lack of value for these markers in the clinical setting. The combined prediction of multiple markers may be needed to improve their predictive efficiency and clinical application value. What is exciting is that some researchers have tried to model this type of joint prediction (77).

In conclusion, there are still many problems to be solved in the study of apatinib-related prognostic biomarkers, and prospectively registered trials with large sample sizes aimed to identify specific markers should be conducted.

\section{DISCUSSION}

To the best of our knowledge, this review is the first to summarize the efficacy and prognostic biomarkers of apatinib in various malignancies over the last 3 years. In this review, we first summarized the efficacy of apatinib against various malignancies in clinical trials where results have been reported. Apatinib is currently approved in China for the treatment of advanced GC and HCC. In addition to these two malignancies, apatinib has been studied in detail against lung cancer, 
TABLE 7 | Response biomarkers of apatinib associated with improved outcomes in the treatment of malignancies.

\begin{tabular}{|c|c|c|c|c|}
\hline $\begin{array}{l}\text { Tumor } \\
\text { species } \\
\text { studied }\end{array}$ & Biomarker Name & $\begin{array}{l}\text { Drugs or } \\
\text { therapies }\end{array}$ & Conclusion & Reference \\
\hline Breast cancer & P-VEGFR2, hypertension & Apatinib & $\begin{array}{l}\text { P-VEGFR2 and hypertension were independent predictive } \\
\text { factors for both PFS and clinical benefit rate. }\end{array}$ & $(70)$ \\
\hline Breast cancer & $\begin{array}{l}\text { No gene variant detected and lower variant allele } \\
\text { frequencies in ctDNA at baseline }\end{array}$ & $\begin{array}{l}\text { Apatinib and } \\
\text { vinorelbine }\end{array}$ & $\begin{array}{l}\text { Patients with no gene variant detected and lower variant allele } \\
\text { frequencies in ctDNA at baseline showed longer PFS. }\end{array}$ & $(56)$ \\
\hline Breast cancer & Hypertension and proteinuria & $\begin{array}{l}\text { Apatinib and oral } \\
\text { etoposide }\end{array}$ & $\begin{array}{l}\text { The median PFS of patients who had hypertension and } \\
\text { proteinuria was longer than that of those without hypertension } \\
\text { and proteinuria. }\end{array}$ & $(53)$ \\
\hline Breast cancer & High percentage of baseline TILs & $\begin{array}{l}\text { Apatinib and } \\
\text { camrelizumab }\end{array}$ & $\begin{array}{l}\text { High percentage of baseline TILs (>10\%) was associated with } \\
\text { higher ORR and favorable PFS. }\end{array}$ & $(54)$ \\
\hline Breast cancer & $\begin{array}{l}\text { Higher baseline TILs or a greater increase of tumor- } \\
\text { infiltrating CD8+ T cells during therapy, lower } \\
\text { baseline plasma HGF/IL-8, a decrease of plasma } \\
\text { IL-8, an increase of plasma TIM-3/CD152 during } \\
\text { therapy, higher baseline CD4+ T cells or B cells } \\
\text { proportion in blood }\end{array}$ & $\begin{array}{l}\text { Apatinib and } \\
\text { camrelizumab }\end{array}$ & $\begin{array}{l}\text { Higher baseline TILs or a greater increase of tumor-infiltrating } \\
\text { CD8+ T cells during therapy, lower baseline plasma HGF/IL-8, } \\
\text { a decrease of plasma IL-8, an increase of plasma TIM-3/ } \\
\text { CD152 during therapy, higher baseline CD4+ T cells or B cells } \\
\text { proportion in blood are potential biomarkers associated with } \\
\text { better outcomes. }\end{array}$ & $(71)$ \\
\hline Cervical & Genetic alterations in PIK3CA, PTEN, ERBB3, and & Apatinib and & Genetic alterations in PIK3CA, PTEN, PI3K/AKT pathway, and & (72) \\
\hline Cancer & PI3K/AKT pathway, as well as TMB. & Camrelizumab & TMB were associated with improved outcomes. & \\
\hline $\begin{array}{l}\text { Colorectal } \\
\text { cancer }\end{array}$ & $\begin{array}{l}\text { Neutrophil/lymphocyte ratio, carbohydrate antigen } \\
\text { 19-9, and HFS }\end{array}$ & Apatinib & $\begin{array}{l}\text { Low baseline neutrophil/lymphocyte ratio, early carbohydrate } \\
\text { antigen 19-9 decrease, and HFS were associated with } \\
\text { improved PFS. }\end{array}$ & $(62)$ \\
\hline Gastric cancer & Hypertension, proteinuria, HFS & Apatinib & $\begin{array}{l}\text { Presence of hypertension, proteinuria, or HFS during the first } \\
\text { cycle of apatinib treatment was a viable biomarker of antitumor } \\
\text { efficacy in metastatic gastric cancer patients. }\end{array}$ & (73) \\
\hline Gastric cancer & Hypertension, proteinuria and/or HFS & Apatinib/paclitaxel & $\begin{array}{l}\text { The occurrence of hypertension, proteinuria and/or HFS were } \\
\text { independent factors associated with better survival outcomes }\end{array}$ & (7) \\
\hline Gastric cancer & Leukopenia, and HFS & $\begin{array}{l}\text { Apatinib and/or } \\
\text { taxel/docetaxel }\end{array}$ & $\begin{array}{l}\text { The potential biomarkers associated with longer PFS were } \\
\text { occurrence of leukopenia and HFS. }\end{array}$ & (8) \\
\hline $\begin{array}{l}\text { Gastric cancer } \\
\text { and lung } \\
\text { cancer }\end{array}$ & Lung cavitation & Apatinib & $\begin{array}{l}\text { Lung cavitation development was beneficial in patients } \\
\text { receiving apatinib therapy regardless of whether they had } \\
\text { primary or metastatic lung cancer. }\end{array}$ & $(74)$ \\
\hline $\mathrm{HCC}$ & PLR & $\begin{array}{l}\text { Apatinib plus } \\
\text { transarterial } \\
\text { chemoembolization }\end{array}$ & $\begin{array}{l}\text { The median PFS and OS in the PLR } \leq 150 \text { group were longer } \\
\text { than those in the PLR }>150 \text { group. }\end{array}$ & $(75)$ \\
\hline $\mathrm{HCC}$ & Hypertension & Apatinib & $\begin{array}{l}\text { Apatinib-related hypertension can potentially predict prolonged } \\
\text { survival. }\end{array}$ & (76) \\
\hline $\mathrm{HCC}$ & The clinical-radiomics nomograms & $\begin{array}{l}\text { Apatinib plus } \\
\text { transarterial } \\
\text { chemoembolization }\end{array}$ & $\begin{array}{l}\text { The clinical-radiomics nomograms, a noninvasive pretreatment } \\
\text { prediction tool that incorporate radiomics signature and AFP, } \\
\text { demonstrated good prediction accuracy for OS and PFS in } \\
\text { these patients. }\end{array}$ & $(77)$ \\
\hline $\mathrm{HCC}$ & LMR, PNI & $\begin{array}{l}\text { Apatinib and } \\
\text { Camrelizumab }\end{array}$ & $\begin{array}{l}\text { The remission rate in patients with high LMR was higher than } \\
\text { that in patients with low LMR, and the remission rate in } \\
\text { patients with high PNI was higher than that in patients with low } \\
\text { PNI. }\end{array}$ & (78) \\
\hline NSCLC & Hypertension & Apatinib & $\begin{array}{l}\text { Hypertension was independently associated with improved } \\
\text { PFS and OS on both univariate and multivariate analyses. }\end{array}$ & (79) \\
\hline NSCLC & STK11/KEAP1 mutation & $\begin{array}{l}\text { Apatinib and } \\
\text { Camrelizumab }\end{array}$ & $\begin{array}{l}\text { Patients with STK11/KEAP1 mutation might derive more } \\
\text { benefits from this combination. }\end{array}$ & $(40)$ \\
\hline $\begin{array}{l}\text { Ovarian } \\
\text { cancer }\end{array}$ & Adipose tissue area & $\begin{array}{l}\text { Apatinib and oral } \\
\text { etoposide }\end{array}$ & $\begin{array}{l}\text { High Adipose tissue area were significantly associated with } \\
\text { better outcomes }\end{array}$ & (80) \\
\hline Osteosarcoma & $\begin{array}{l}\text { Anorexia, hypertension, pneumothorax, and } \\
\text { hypothyroidism }\end{array}$ & Apatinib & $\begin{array}{l}\text { Anorexia, hypertension, pneumothorax, and hypothyroidism } \\
\text { might be markers for a favorable clinical outcome following } \\
\text { apatinib- treated refractory osteosarcoma. }\end{array}$ & (81) \\
\hline Osteosarcoma & Pneumothorax and cavitation in lung metastases & Apatinib & $\begin{array}{l}\text { Pneumothorax and cavitation in lung metastases may be } \\
\text { effective prognostic markers. }\end{array}$ & (82) \\
\hline Sarcoma & $\begin{array}{l}\text { Hypertension, proteinuria, } \\
\text { HFS }\end{array}$ & Apatinib & $\begin{array}{l}\text { The development of hypertension, HFS, or proteinuria may } \\
\text { indicate a favorable prognosis. }\end{array}$ & $(44)$ \\
\hline Sarcoma & $\begin{array}{l}\text { Hypertension, proteinuria, } \\
\text { HFS }\end{array}$ & Apatinib & $\begin{array}{l}\text { The subjects who experienced hypertension, HFS, or } \\
\text { proteinuria had significantly longer OS than those without these } \\
\text { AEs }\end{array}$ & $(47)$ \\
\hline $\begin{array}{l}\text { Thyroid } \\
\text { cancer }\end{array}$ & BRAFV600E mutation & Apatinib & $\begin{array}{l}\text { Patients with BRAFV600E mutation had a longer median PFS } \\
\text { compared with patients with BRAF wild-type. }\end{array}$ & $(68)$ \\
\hline
\end{tabular}

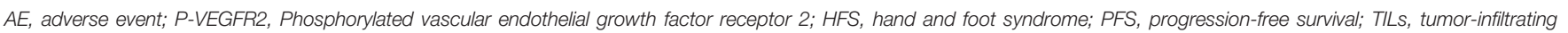

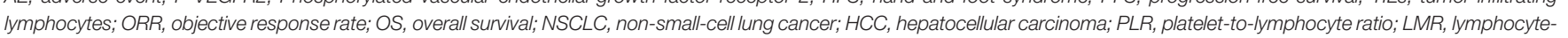
to-monocyte ratio; PNI, prognostic nutritional index. 
TABLE 8 | Response biomarkers of apatinib associated with poor outcomes in the treatment of malignancies.

\begin{tabular}{|c|c|c|c|c|}
\hline $\begin{array}{l}\text { Tumor species } \\
\text { studied }\end{array}$ & Biomarker Name & Drugs or therapies & Conclusion & Referenc \\
\hline Breast cancer & Gene variants in ctDNA & $\begin{array}{l}\text { Apatinib in combination } \\
\text { with oral vinorelbine }\end{array}$ & $\begin{array}{l}\text { Patients with no gene variant detected and lower variant allele frequencies } \\
\text { in ctDNA at baseline showed longer PFS. }\end{array}$ & $(56)$ \\
\hline Cervical Cancer & ERBB3 mutations & $\begin{array}{l}\text { Apatinib and } \\
\text { Camrelizumab }\end{array}$ & ERBB3 mutations correlated with poor survival. & (72) \\
\hline Gastric cancer & CEA elevation & Apatinib & $\begin{array}{l}\text { CEA elevation was considered to be a potential independent predictive } \\
\text { factor associated with shorter PFS and OS. }\end{array}$ & (13) \\
\hline $\begin{array}{l}\text { Nasopharyngeal } \\
\text { carcinoma }\end{array}$ & EBV DNA titer & Apatinib & $\begin{array}{l}\text { High EBV DNA titer were significant prognostic factors associated with } \\
\text { shorter PFS. }\end{array}$ & (83) \\
\hline $\begin{array}{l}\text { Non-small- cell } \\
\text { lung cancer }\end{array}$ & $\begin{array}{l}\text { cfDNA concentration, } \\
\text { MIKI67 mutations and HPD- } \\
\text { related mutations }\end{array}$ & $\begin{array}{l}\text { Apatinib and } \\
\text { Camrelizumab }\end{array}$ & $\begin{array}{l}\text { High cfDNA concentration, MIKI67 mutations and HPD-related mutations } \\
\text { were independent risk factors and worse PFS predictors for apatinib and } \\
\text { camrelizumab combined therapy. }\end{array}$ & (84) \\
\hline $\begin{array}{l}\text { Non-squamous } \\
\text { non-small cell } \\
\text { lung cancer }\end{array}$ & $\begin{array}{l}\text { Presence of CNS metastasis } \\
\text { at baseline }\end{array}$ & $\begin{array}{l}\text { Apatinib in combination } \\
\text { with pemetrexed-platinum } \\
\text { chemotherapy }\end{array}$ & $\begin{array}{l}\text { The mPFS in the responders without CNS metastasis at baseline was } \\
\text { significantly longer than that in those with presence of CNS metastasis at } \\
\text { baseline. }\end{array}$ & $(36)$ \\
\hline
\end{tabular}

PFS, progression-free survival; OS, overall survival; EBV DNA, Epstein-Barr virus DNA; CNS, central nervous system.

breast cancer, and sarcoma. Apatinib has a great application value for the treatment of these tumor species. Moreover, the efficacy of apatinib against esophageal cancer, colorectal cancer, ovarian cancer, cervical cancer, cholangiocarcinoma, diffuse large B-cell lymphoma, nasopharyngeal carcinoma, and differentiated thyroid cancer has been proven in prospectively registered trials. Additionally, we reviewed the current literature on biomarkers of apatinib response. According to their properties, these biomarkers can be divided into three categories: adverse event, routine test, and genetic test markers. The findings of this review have a good reference value for the application of apatinib in clinical studies and the design of clinical trials.

This review identified some problems and phenomena in apatinib treatment. The first is the narrow range of apatinib monotherapy scenarios. As a monotherapy regimen, apatinib may be difficult to be approved for additional cancer indications. Long-term, off-label use of apatinib may be required for the treatment of malignancies other than GC and HCC. Second, clinical trials of apatinib in combination with other drugs or therapies are still in the early stages of development. It seems that apatinib can be used in combination with other anticancer therapies. Currently, the most studied is the combination of apatinib and camrelizumab (a PD-1 inhibitor from the same manufacturer). Studies on apatinib in combination with common chemotherapeutic agents are also increasing. We predict that the next approved clinical indication for apatinib is likely to be in the form of combination therapy with other drugs or therapies. Third, the optimal scenario for apatinib in most malignancies is unclear. Although apatinib monotherapy is approved for advanced GC and advanced HCC, combination regimens based on apatinib may be more effective. Current evidence suggests that apatinib monotherapy in many malignancies is not a substitute for existing mature regimens, but the optimal use of apatinib in a particular cancer (e.g., as a monotherapy or in combination? Combination with which agent or therapy? As a neoadjuvant or advanced multiline therapy?) is unclear. Finally, the current research on response biomarkers of apatinib is limited. On the one hand, the current level of evidence obtained by apatinib prognostic marker studies is not high. On the other hand, even though many therapeutic markers have been reported and each therapeutic marker has a different predictive value in different tumor species, the overall predictive efficiency is not high.

To solve these problems, the next clinical study of apatinib can follow three major directions. The first is to further expand the use of apatinib in different malignancies. There are hundreds of types of malignant tumors (85), and as a late-marketed multitarget TKI, apatinib has fewer clinical trials compared with other multitarget TKIs in the same class, such as pazopanib and sorafenib $(86,87)$. Prospective, registered clinical trials of apatinib should be conducted for various malignancies that respond to multitarget TKIs. The second is to continue to expand and determine the best application scenarios of apatinib for specific tumor species. Third, through a systematic study of the available evidence on response biomarkers of apatinib, we established that there are some effective response biomarkers for this drug. However, to improve the level of evidence and our understanding of these biomarkers, prospective registration trials with large sample sizes focusing on specific biomarkers should be conducted.

In conclusion, this review summarized the current knowledge on the efficacy and response biomarkers of apatinib for malignancy treatment, highlighted the current problems to be solved in the clinical application of apatinib, and proposed promising directions for future clinical research. Although much work remains to be done, apatinib will eventually advance from a new targeted drug for many malignancies to a cornerstone drug, similar to cyclophosphamide and doxorubicin among common chemotherapy drugs.

\section{AUTHOR CONTRIBUTIONS}

All authors listed have made a substantial, direct, and intellectual contribution to the work, and approved it for publication. 


\section{REFERENCES}

1. Tian S, Quan H, Xie C, Guo H, Lu F, Xu Y, et al. YN968D1 Is a Novel and Selective Inhibitor of Vascular Endothelial Growth Factor Receptor-2 Tyrosine Kinase With Potent Activity In Vitro and In Vivo. Cancer Sci (2011) 102:1374-80. doi: 10.1111/j.1349-7006.2011.01939.x

2. Roviello G, Ravelli A, Polom K, Petrioli R, Marano L, Marrelli D, et al. Apatinib: A Novel Receptor Tyrosine Kinase Inhibitor for the Treatment Gastric Cancer. Cancer Lett (2016) 372:187-91. doi: 10.1016/j.canlet. 2016.01.014

3. Scott LJ. Apatinib: A Review in Advanced Gastric Cancer and Other Advanced Cancers. Drugs (2018) 78:747-58. doi: 10.1007/s40265-018-0903-9

4. Zhao D, Hou H, Zhang X. Progress in the Treatment of Solid Tumors With Apatinib: A Systematic Review. Onco Targets Ther (2018) 11:4137-47. doi: 10.2147/OTT.S172305

5. Li J, Qin S, Xu J, Guo W, Xiong J, Bai Y, et al. Apatinib for ChemotherapyRefractory Advanced Metastatic Gastric Cancer: Results From a Randomized, Placebo-Controlled, Parallel-Arm, Phase II Trial. J Clin Oncol (2013) 31:3219-25. doi: 10.1200/JCO.2013.48.8585

6. Li J, Qin S, Xu J, Xiong J, Wu C, Bai Y, et al. Randomized, Double-Blind, Placebo-Controlled Phase III Trial of Apatinib in Patients With Chemotherapy-Refractory Advanced or Metastatic Adenocarcinoma of the Stomach or Gastroesophageal Junction. J Clin Oncol (2016) 34:1448-54. doi: 10.1200/JCO.2015.63.5995

7. Peng W, Zhang F, Wang Z, Li D, He Y, Ning Z, et al. Large Scale, Multicenter, Prospective Study of Apatinib in Advanced Gastric Cancer: A Real-World Study From China. Cancer Manag Res (2020) 12:6977-85. doi: 10.2147/ CMAR.S249153

8. Shen B, Jiang H, Wang L, Qian J, Shu Y, Chen P, et al. Effectiveness and Safety of Apatinib in Patients With Advanced or Metastatic Adenocarcinoma of Stomach or Gastroesophageal Junction: A Prospective Observation Study. Onco Targets Ther (2020) 13:4457-64. doi: 10.2147/OTT.S232287

9. Wang X, Yu J, Yang M, Liu L, Gao J, Ren Y, et al. Safety and Effectiveness of Apatinib in Patients With Previously Treated Metastatic Gastric Cancer: A Sub-Analysis From the Real-World Study of Apatinib for Gastric Cancer Treatment (AHEAD-G202). Am J Cancer Res (2020) 10:987-96.

10. Zhao S, Fan N, Li H, Liu J, Huang F, Chen Y, et al. Apatinib Combined With Paclitaxel-Based Chemotherapy in Patients With Taxane-Resistant Advanced Gastric Cancer: A Single-Arm Exploratory Study. Ann Transl Med (2020) 8:1233. doi: 10.21037/atm-20-5841

11. Zheng Y, Yang X, Yan C, Feng R, Sah BK, Yang Z, et al. Effect of Apatinib Plus Neoadjuvant Chemotherapy Followed by Resection on Pathologic Response in Patients With Locally Advanced Gastric Adenocarcinoma: A Single-Arm, Open-Label, Phase II Trial. Eur J Cancer (2020) 130:12-9. doi: 10.1016/ j.ejca.2020.02.013

12. Zhou N, Zhang C, Liu D, Liu K, Wang G, Zhu H, et al. Apatinib in Combination With S-1 as First-Line Treatment in Patients With Advanced Metastatic Gastric Cancer: Results From an Open, Exploratory, Single-Arm, Phase II Trial. Oncologist (2021) 26:e374-81. doi: 10.1002/onco.13613

13. Li N, Bai C, Zhang R, Ma L, Ren X, Zhang J, et al. Efficacy and Safety of Apatinib for the Treatment of AFP-Producing Gastric Cancer. Transl Oncol (2021) 14:101004. doi: 10.1016/j.tranon.2020.101004

14. Peng Z, Wei J, Wang F, Ying J, Deng Y, Gu K, et al. Camrelizumab Combined With Chemotherapy Followed by Camrelizumab Plus Apatinib as FirstLine Therapy for Advanced Gastric or Gastroesophageal Junction Adenocarcinoma. Clin Cancer Res (2021) 27:3069-78. doi: 10.1158/10780432.CCR-20-4691

15. Geng R, Li J. Apatinib for the Treatment of Gastric Cancer. Expert Opin Pharmacother (2015) 16:117-22. doi: 10.1517/14656566.2015.981526

16. Fornaro L, Vasile E, Falcone A. Apatinib in Advanced Gastric Cancer: A Doubtful Step Forward. J Clin Oncol (2016) 34:3822-3. doi: 10.1200/ JCO.2016.68.6931

17. Aoyama T, Yoshikawa T. Targeted Therapy: Apatinib - New Third-Line Option for Refractory Gastric or GEJ Cancer. Nat Rev Clin Oncol (2016) 13:268-70. doi: 10.1038/nrclinonc.2016.53

18. Lee HJ, Moon JY, Baek SW. Is Treatment-Emergent Toxicity a Biomarker of Efficacy of Apatinib in Gastric Cancer? J Clin Oncol (2016) 34:3823. doi: $10.1200 / J C O .2016 .68 .8663$
19. Zhang S. Problematic Analysis and Inadequate Toxicity Data in Phase III Apatinib Trial in Gastric Cancer. J Clin Oncol (2016) 34:3821-1. doi: 10.1200/ JCO.2016.67.3889

20. Wang X, Zhang R, Du N, Yang M, Zang A, Liu L, et al. An Open Label, Multicenter, Noninterventional Study of Apatinib in Advanced Gastric Cancer Patients (AHEAD-G202). Ther Adv Med Oncol (2020) 12:1758835920905424. doi: $10.1177 / 1758835920905424$

21. Lu W, Jin X-L, Yang C, Du P, Jiang F-Q, Ma J-P, et al. Comparison of Efficacy Between TACE Combined With Apatinib and TACE Alone in the Treatment of Intermediate and Advanced Hepatocellular Carcinoma: A Single-Center Randomized Controlled Trial. Cancer Biol Ther (2017) 18:433-8. doi: 10.1080/15384047.2017.1323589

22. Hou Z, Zhu K, Yang X, Chen P, Zhang W, Cui Y, et al. Apatinib as First-Line Treatment in Patients With Advanced Hepatocellular Carcinoma: A Phase II Clinical Trial. Ann Transl Med (2020) 8:1047. doi: 10.21037/atm-20-2990

23. Sun HC, Zhu XD, Zhou J, Gao Q, Shi YH, Ding ZB, et al. Adjuvant Apatinib Treatment After Resection of Hepatocellular Carcinoma With Portal Vein Tumor Thrombosis: A Phase II Trial. Ann Transl Med (2020) 8:1301. doi: $10.21037 / \mathrm{atm}-20-6181$

24. Xu J, Shen J, Gu S, Zhang Y, Wu L, Wu J, et al. Camrelizumab in Combination With Apatinib in Patients With Advanced Hepatocellular Carcinoma (RESCUE): A Nonrandomized, Open-Label, Phase II Trial. Clin Cancer Res (2021) 27:1003-11. doi: 10.1158/1078-0432.CCR-20-2571

25. Mei K, Qin S, Chen Z, Liu Y, Wang L, Zou J. Camrelizumab in Combination With Apatinib in Second-Line or Above Therapy for Advanced Primary Liver Cancer: Cohort A Report in a Multicenter Phase Ib/II Trial. J Immunother Cancer (2021) 9:e002191. doi: 10.1136/jitc-2020-002191

26. Qin S, Li Q, Gu S, Chen X, Lin L, Wang Z, et al. Apatinib as Second-Line or Later Therapy in Patients With Advanced Hepatocellular Carcinoma (AHELP): A Multicentre, Double-Blind, Randomised, Placebo-Controlled, Phase 3 Trial. Lancet Gastroenterol Hepatol (2021) 6:559-68. doi: 10.1016/ S2468-1253(21)00109-6

27. Pinato DJ, Fessas P, Cortellini A, Rimassa L. Combined PD-1/VEGFR Blockade: A New Era of Treatment for Hepatocellular Cancer. Clin Cancer Res (2021) 27:908-10. doi: 10.1158/1078-0432.CCR-20-4069

28. Wu F, Zhang S, Xiong A, Gao G, Li W, Cai W, et al. A Phase II Clinical Trial of Apatinib in Pretreated Advanced Non-Squamous Non-Small-Cell Lung Cancer. Clin Lung Cancer (2018) 19:e831-42. doi: 10.1016/j.cllc.2018.06.002

29. Duan JC, Wang ZJ, Lin L, Li JL, Wang Y, Bai H, et al. Apatinib, a Novel VEGFR Inhibitor Plus Docetaxel in Advanced Lung Adenocarcinoma Patients With Wild-Type EGFR: A Phase I Trial. Invest New Drugs (2019) 37:731-7. doi: 10.1007/s10637-019-00735-1

30. Luo H, Zhang L, Yang B, Feng Y, Xiong Y, Zhang S, et al. A Randomized Phase 2 Trial of Apatinib vs Observation as Maintenance Treatment Following FirstLine Induction Chemotherapy in Extensive Stage Small Cell Lung Cancer. Invest New Drugs (2019) 38:148-59. doi: 10.1007/s10637-019-00828-x

31. Xu Y, Huang Z, Lu H, Yu X, Li Y, Li W, et al. Apatinib in Patients With Extensive-Stage Small-Cell Lung Cancer After Second-Line or Third-Line Chemotherapy: A Phase II, Single-Arm, Multicentre, Prospective Study. Br J Cancer (2019) 121:640-6. doi: 10.1038/s41416-019-0583-6

32. Fan Y, Zhao J, Wang Q, Huang D, Li X, Chen J, et al. Camrelizumab Plus Apatinib in Extensive-Stage SCLC (PASSION): A Multicenter, Two-Stage, Phase 2 Trial. J Thorac Oncol (2021) 16:299-309. doi: 10.1016/ j.jtho.2020.10.002

33. Geng Q, Shen H, Zhu W, Lu Y, Wang M, Jiang H, et al. Safety and Efficacy of Low-Dosage Apatinib Monotherapy in Advanced Lung Squamous-Cell Carcinoma: A Prospective Cohort Study. Onco Targets Ther (2020) 13:11529-35. doi: 10.2147/OTT.S277532

34. Liu Y, Hu X, Jiang J, Yang L, Zhou S, Liu P, et al. A Prospective Study of Apatinib in Patients With Extensive-Stage Small Cell Lung Cancer After Failure of Two or More Lines of Chemotherapy. Oncologist (2020) 25:e83342. doi: 10.1634/theoncologist.2019-0391

35. Song Y, Miao L, Wang Z, Shi M. Combination of Apatinib and Docetaxel in Treating Advanced Non-Squamous Non-Small Cell Lung Cancer Patients With Wild-Type EGFR: A Multi-Center, Phase II Trial. J Thorac Dis (2020) 12:2450-8. doi: $10.21037 /$ jtd.2020.03.54

36. Yang G, Xu H, Yang L, Xu F, Zhang S, Yang Y, et al. Apatinib in Combination With Pemetrexed-Platinum Chemotherapy for Chemo-Naive Non-Squamous 
Non-Small Cell Lung Cancer: A Phase II Clinical Study. Lung Cancer (2020) 147:229-36. doi: 10.1016/j.lungcan.2020.07.024

37. Yu Z, Cai X, Xu Z, He Z, Lai J, Wang W, et al. Apatinib Plus Chemotherapy as a Second-Line Treatment in Unresectable Non-Small Cell Lung Carcinoma: A Randomized, Controlled, Multicenter Clinical Trial. Oncologist (2020) 25: e1640-9. doi: 10.1634/theoncologist.2020-0519

38. Zhang X, Xiong Y, Xia Q, Wu F, Liu L, Zhou Y, et al. Efficacy and Safety of Apatinib Plus Vinorelbine in Patients With Wild-Type Advanced Non-Small Cell Lung Cancer After Second-Line Treatment Failure: A Nonrandomized Clinical Trial. JAMA Netw Open (2020) 3:e201226. doi: 10.1001/ jamanetworkopen.2020.1226

39. Zhang Z, Zhang Y, Luo F, Ma Y, Fang W, Zhan J, et al. Dual Blockade of EGFR and VEGFR Pathways: Results From a Pilot Study Evaluating Apatinib Plus Gefitinib as a First-Line Treatment for Advanced EGFR-Mutant Non-Small Cell Lung Cancer. Clin Transl Med (2020) 10:e33. doi: 10.1002/ctm2.33

40. Zhou C, Wang Y, Zhao J, Chen G, Liu Z, Gu K, et al. Efficacy and Biomarker Analysis of Camrelizumab in Combination With Apatinib in Patients With Advanced Nonsquamous NSCLC Previously Treated With Chemotherapy. Clin Cancer Res (2021) 27:1296-304. doi: 10.1158/10780432.CCR-20-3136

41. He Z, Zhou H, Wang J, Li D, Zhang X, Wang P, et al. Apatinib With Etoposide Capsules as a Third- or Further-Line Therapy for Extensive-Stage Small Cell L Lung Cancer: An Open-Label, Multicenter, Single-Arm Phase II Trial. Transl Lung Cancer Res (2021) 10:889-99. doi: 10.21037/tlcr-20-1235

42. Zhao H, Yao W, Min X, Gu K, Yu G, Zhang Z, et al. Apatinib Plus Gefitinib as First-Line Treatment in Advanced EGFR-Mutant NSCLC: The Phase III ACTIVE Study (CTONG1706). J Thorac Oncol (2021) 16:299-309. doi: 10.1016/j.jtho.2021.05.006

43. Schulte B, Mohindra N, Milhem M, Attia S, Robinson S, Monga V, et al. Phase II Study of Pazopanib With Oral Topotecan in Patients With Metastatic and Non-Resectable Soft T Issue and Bone Sarcomas. Br J Cancer (2021) 125:52833. doi: 10.1038/s41416-021-01448-0

44. Liao Z, Li F, Zhang C, Zhu L, Shi Y, Zhao G, et al. Phase II Trial of VEGFR2 Inhibitor Apatinib for Metastatic Sarcoma: Focus on Efficacy and Safety. Exp Mol Med (2019) 51:1-11. doi: 10.1038/s12276-019-0221-7

45. Xie L, Xu J, Sun X, Tang X, Yan T, Yang R, et al. Apatinib for Advanced Osteosarcoma After Failure of Standard Multimodal Therapy: An Open Label Phase II Clinical Trial. Oncologist (2019) 24:e542-50. doi: 10.1634/ theoncologist.2018-0542

46. Liu C, Jia Q, Wei H, Yang X, Liu T, Zhao J, et al. Apatinib in Patients With Advanced Chordoma: A Single-Arm, Single-Centre, Phase 2 Study. Lancet Oncol (2020) 21:1244-52. doi: 10.1016/S1470-2045(20)30466-6

47. Liu X, Xu J, Li F, Liao Z, Ren Z, Zhu L, et al. Efficacy and Safety of the VEGFR2 Inhibitor Apatinib for Metastatic Soft Tissue Sarcoma: Chinese Cohort Data From NCT03121846. BioMed Pharmacother (2020) 122:109587. doi: 10.1016/ j.biopha.2019.109587

48. Xie L, Xu J, Sun X, Guo W, Gu J, Liu K, et al. Apatinib Plus Camrelizumab (Anti-PD1 Therapy, SHR-1210) for Advanced Osteosarcoma (APFAO) Progressing After Chemotherapy: A Single-Arm, Open-Label, Phase 2 Trial. J Immunother Cancer (2020) 8:e000798. doi: 10.1136/jitc-2020-000798

49. Tawbi HA, Burgess M, Bolejack V, Van Tine BA, Schuetze SM, Hu J, et al. Pembrolizumab in Advanced Soft-Tissue Sarcoma and Bone Sarcoma (SARC028): A Multicentre, Two-Cohort, Single-Arm, Open-Label, Phase 2 Trial. Lancet Oncol (2017) 18:1493-501. doi: 10.1016/S1470-2045(17)30624-1

50. Wilky BA, Trucco MM, Subhawong TK, Florou V, Park W, Kwon D, et al. Axitinib Plus Pembrolizumab in Patients With Advanced Sarcomas Including Alveolar Soft-Part Sarcoma: A Single-Centre, Single-Arm, Phase 2 Trial. Lancet Oncol (2019) 20:837-48. doi: 10.1016/S1470-2045(19)30153-6

51. Hu X, Cao J, Hu W, Wu C, Pan Y, Cai L, et al. Multicenter Phase II Study of Apatinib in Non-Triple-Negative Metastatic Breast Cancer. BMC Cancer (2014) 14:820. doi: 10.1186/1471-2407-14-820

52. Hu X, Zhang J, Xu B, Jiang Z, Ragaz J, Tong Z, et al. Multicenter Phase II Study of Apatinib, A Novel VEGFR Inhibitor in Heavily Pretreated Patients With Metastatic Triple-Negative Breast Cancer. Int J Cancer (2014) 135:19619. doi: 10.1002/ijc.28829

53. Hu N, Zhu A, Si Y, Yue J, Wang X, Wang J, et al. A Phase II, Single-Arm Study of Apatinib and Oral Etoposide in Heavily Pre-Treated Metastatic Breast Cancer. Front Oncol (2020) 10:565384. doi: 10.3389/fonc.2020.565384
54. Liu J, Liu Q, Li Y, Li Q, Su F, Yao H, et al. Efficacy and Safety of Camrelizumab Combined With Apatinib in Advanced Triple-Negative Breast Cancer: An Open-Label Phase II Trial. J Immunother Cancer (2020) 8:e000696. doi: 10.1136/jitc-2020-000696

55. Li H, Geng C, Zhao H, Jiang H, Song G, Zhang J, et al. Multicenter Phase II Study of Apatinib Single or Combination Therapy in HER2-Negative Breast Cancer Involving Chest Wall Metastasis. Chin J Cancer Res (2021) 33:243-55. doi: 10.21147/j.issn.1000-9604.2021.02.11

56. Zhu A, Yuan P, Hu N, Li M, Wang W, Wang X, et al. Phase II Study of Apatinib in Combination With Oral Vinorelbine in Heavily Pretreated HER2Negative Metastatic Breast Cancer and Clinical Implications of Monitoring ctDNA. Cancer Biol Med (2021) 18(3):875-87. doi: 10.20892/j.issn.20953941.2020 .0418

57. Yanwei L, Feng H, Ren P, Yue J, Zhang W, Tang P, et al. Safety and Efficacy of Apatinib Monotherapy for Unresectable, Metastatic Esophageal Cancer: A Single-Arm, Open-Label, Phase II Study. Oncologist (2020) 25:e1464-72. doi: 10.1634/theoncologist.2020-0310

58. Chu L, Chen Y, Liu Q, Liang F, Wang S, Liu Q, et al. A Phase II Study of Apatinib in Patients With Chemotherapy-Refractory Advanced Or Metastatic Esophageal Squamous Cell Carcinoma (ESO-Shanghai 11). Oncologist (2021) 26:e925-35. doi: 10.1002/onco.13668

59. Zhang B, Qi L, Wang X, Xu J, Liu Y, Mu L, et al. Phase II Clinical Trial Using Camrelizumab Combined With Apatinib and Chemotherapy as the First-Line Treatment of Advanced Esophageal Squamous Cell Carcinoma. Cancer Commun (2020) 40:711-20. doi: 10.1002/cac2.12119

60. Chen X, Qiu T, Zhu Y, Sun J, Li P, Wang B, et al. A Single-Arm, Phase II Study of Apatinib in Refractory Metastatic Colorectal Cancer. Oncologist (2019) 24:883-e407. doi: 10.1634/theoncologist.2019-0164

61. Ren C, Mai ZJ, Jin Y, He MM, Wang ZQ, Luo HY, et al. Anti-PD-1 Antibody SHR-1210 Plus Apatinib for Metastatic Colorectal Cancer: A Prospective, Single-Arm, Open-Label, Phase II Trial. Am J Cancer Res (2020) 10:2946-54.

62. Wang F, Yuan X, Jia J, Bi X, Zhou Z, Zhou Q, et al. Apatinib Monotherapy for Chemotherapy-Refractory Metastatic Colorectal Cancer: A Multi-Centre, Single-Arm, Prospective Study. Sci Rep (2020) 10:6058. doi: 10.1038/s41598020-62961-5

63. Lan C-Y, Wang Y, Xiong Y, Li J-D, Shen J-X, Li Y-F, et al. Apatinib Combined With Oral Etoposide in Patients With Platinum-Resistant or PlatinumRefractory Ovarian Cancer (AEROC): A Phase 2, Single-Arm, Prospective Study. Lancet Oncol (2018) 19:1239-46. doi: 10.1016/S1470-2045(18)30349-8

64. Lan C, Shen J, Wang Y, Li J, Liu Z, He M, et al. Camrelizumab Plus Apatinib in Patients With Advanced Cervical Cancer (CLAP): A Multicenter, Open-Labe L, Single-Arm, Phase II Trial. J Clin Oncol (2020) 38:4095-106. doi: 10.1200/ JCO.20.01920

65. Mao J, Yang X, Lin J, Yang X, Wang D, Zhang L, et al. Apatinib as Non-FirstLine Treatment in Patients With Intrahepatic Cholangiocarcinoma. J Cancer (2021) 12:1555-62. doi: 10.7150/jca.53482

66. Ma X, Li L, Zhang L, Fu X, Li X, Wang X, et al. Apatinib in Patients With Relapsed or Refractory Diffuse Large B Cell Lymphoma: A Phase II, OpenLabel, Single-Arm, Prospective Study. Drug Des Devel Ther (2020) 14:275-84. doi: 10.2147/DDDT.S227477

67. Ruan X, Liang JH, Pan Y, Cai R, Zhang RJ, He Z, et al. Apatinib for the Treatment of Metastatic or Locoregionally Recurrent Nasopharyngeal Carcinoma After Failure of Chemotherapy: A Multicenter, Single-Arm, Prospective Phase 2 Study. Cancer (2021) 127(17):3163-71. doi: 10.1002/cncr.33626

68. Lin YS, Zhang X, Wang C, Liu YQ, Guan WM, Liang J. Long-Term Results of Phase II Trial of Apatinib for Progressive Radioiodine Refractory Differentiated Thyroid Cancer. J Clin Endocrinol Metab (2021) 106:e302736. doi: $10.1210 /$ clinem/dgab196

69. Gourley C. Apatinib and Etoposide: Surprising Efficacy of an Oral Combination. Lancet Oncol (2018) 19:1146-7. doi: 10.1016/S1470-2045(18)30444-3

70. Fan M, Zhang J, Wang Z, Wang B, Zhang Q, Zheng C, et al. Phosphorylated VEGFR2 and Hypertension: Potential Biomarkers to Indicate VEGFDependency of Advanced Breast Cancer in Anti-Angiogenic Therapy. Breast Cancer Res Treat (2014) 143:141-51. doi: 10.1007/s10549-013-2793-6

71. Liu J, Li Y, Li Q, Liang D, Wang Q, Liu Q. Biomarkers of Response to Camrelizumab Combined With Apatinib: An Analysis From a Phase II Trial in Advanced Triple-Negative Breast Cancer Patients. Breast Cancer Res Treat (2021) 186:687-97. doi: 10.1007/s10549-021-06128-4 
72. Huang X, He M, Peng H, Tong C, Liu Z, Zhang X, et al. Genomic Profiling of Advanced Cervical Cancer to Predict Response to Programmed Death-1 Inhibitor Combination Therapy: A Secondary Analysis of the CLAP Trial. J Immunother Cancer (2021) 9:e002223. doi: 10.1136/jitc-2020-002223

73. Liu X, Qin S, Wang Z, Xu J, Xiong J, Bai Y, et al. Early Presence of AntiAngiogenesis-Related Adverse Events as a Potential Biomarker of Antitumor Efficacy in Metastatic Gastric Cancer Patients Treated With Apatinib: A Cohort Study. J Hematol Oncol (2017) 10:153. doi: 10.1186/s13045-017-0521-0

74. Jiang $M$, Zhang C, Liu D, Wang $\mathrm{Y}$, Wang $\mathrm{H}$, Li $\mathrm{T}$, et al. Influence and Mechanism of Lung Cavitation Development on Antiangiogenic Therapy. Transl Lung Cancer Res (2019) 8:500-12. doi: 10.21037/tlcr.2019.07.01

75. Chen L, Ke Z, Xiong F, Kan X, Ren Y, Cao Y, et al. Platelet-To-Lymphocyte Ratio Predicts Therapy Outcomes of Transarterial Chemoembolization Plus Apatinib in the Treatment of Advanced Hepatocellular Carcinoma. Anticancer Drugs (2020) 31:966-72. doi: 10.1097/CAD.0000000000000913

76. Yang X, Hou Z, Zhu K, Zhang S, Gu X, Wang Z, et al. Drug-Related Hypertension Associated With the Efficacy of Apatinib on Hepatocellular Carcinoma. Cancer Manag Res (2020) 12:3163-73. doi: 10.2147/CMAR.S240394

77. Li L, Kan X, Zhao Y, Liang B, Ye T, Yang L, et al. Radiomics Signature: A Potential Biomarker for the Prediction of Survival in Advanced Hepatocellular Carcinoma. Int J Med Sci (2021) 18:2276-84. doi: 10.7150/ijms.55510

78. Zeng Z, Jiang Y, Liu C, Zhu G, Ma F, Yang L, et al. Efficacy and Biomarker Exploration of Camrelizumab Combined With Apatinib in the Treatment of Advanced Primary Liver Cancer: A Retrospective Study. Anticancer Drugs (2021). doi: 10.1097/CAD.0000000000001127

79. Fang S, Huang W, Zhang Y, Zhang $\mathrm{H}$ and Xie W. Hypertension as a Predictive Biomarker in Patients With Advanced Non-Small-Cell Lung Cancer Treated With Apatinib. Onco Targets Ther (2019) 12:985-92. doi: 10.2147/OTT.S189984

80. Huang X, Xie C, Tang J, He W, Yang F, Tian W, et al. Adipose Tissue Area as a Predictor for the Efficacy of Apatinib in Platinum-Resistant Ovarian Cancer: An Exploratory Imaging Biomarker Analysis of the AEROC Trial. BMC Med (2020) 18:267. doi: 10.1186/s12916-020-01733-4

81. Xie L, Xu J, Sun X, Tang X, Yan T, Yang R, et al. Anorexia, Hypertension, Pneumothorax, and Hypothyroidism: Potential Signs of Improved Clinical Outcome Following Apatinib in Advanced Osteosarcoma. Cancer Manag Res (2020) 12:91-102. doi: 10.2147/CMAR.S232823

82. Tian Z, Liu H, Zhao Y, Wang X, Ren H, Zhang F, et al. Secondary Pneumothorax as a Potential Marker of Apatinib Efficacy in Osteosarcoma:
A Multicenter Analysis. Anticancer Drugs (2021) 32:82-7. doi: 10.1097/ CAD.0000000000001016

83. Huang L, Zhang X, Bai Y, Chua K, Xie Y, Shu X, et al. Efficacy and Safety of Apatinib in Recurrent/Metastatic Nasopharyngeal Carcinoma: A Pilot Study. Oral Oncol (2021) 115:105222. doi: 10.1016/j.oraloncology.2021.105222

84. Chen Y, Li X, Liu G, Chen S, Xu M, Song L, et al. ctDNA Concentration, MIKI67 Mutations and Hyper-Progressive Disease Related Gene Mutations Are Prognostic Markers for Camrelizumab and Apatinib Combined Multiline Treatment in Advanced NSCLC. Front Oncol (2020) 10:1706. doi: 10.3389/ fonc. 2020.01706

85. Sung H, Ferlay J, Siegel RL, Laversanne M, Soerjomataram I, Jemal A, et al. Global Cancer Statistics 2020: GLOBOCAN Estimates of Incidence and Mortality Worldwide for 36 Cancers in 185 Countries. CA Cancer J Clin (2021) 71:209-49. doi: 10.3322/caac.21660

86. Escudier B, Worden F, Kudo M. Sorafenib: Key Lessons From Over 10 Years of Experience. Expert Rev Anticancer Ther (2019) 19:177-89. doi: 10.1080/ 14737140.2019.1559058

87. Wilding CP, Elms ML, Judson I, Tan AC, Jones RL, Huang PH. The Landscape of Tyrosine Kinase Inhibitors in Sarcomas: Looking Beyond Pazopanib. Expert Rev Anticancer Ther (2019) 19:971-91. doi: 10.1080/ 14737140.2019.1686979

Conflict of Interest: The authors declare that the research was conducted in the absence of any commercial or financial relationships that could be construed as a potential conflict of interest.

Publisher's Note: All claims expressed in this article are solely those of the authors and do not necessarily represent those of their affiliated organizations, or those of the publisher, the editors and the reviewers. Any product that may be evaluated in this article, or claim that may be made by its manufacturer, is not guaranteed or endorsed by the publisher.

Copyright (c) 2021 Tian, Niu and Yao. This is an open-access article distributed under the terms of the Creative Commons Attribution License (CC BY). The use, distribution or reproduction in other forums is permitted, provided the original author(s) and the copyright owner(s) are credited and that the original publication in this journal is cited, in accordance with accepted academic practice. No use, distribution or reproduction is permitted which does not comply with these terms. 